\title{
Excel VBAを利用したビジュアルな伝熱解析ツールの開発*
}

\author{
小系 康志 ${ }^{\circ}$ (熊本大学)，富村 寿夫（熊本大学），鳥居 修一（熊本大学）

\section{Development of a Visual Tool for Heat Transfer Analysis Using Excel VBA}

\author{
Yasushi KoITO, Toshio TOMIMURA and Shuichi TORII
}

\begin{abstract}
Microsoft Excel has been used for scientific numerical simulation. In Excel simulation, each cell of a spreadsheet is regarded as a nodal point. Based on a concrete image of a physical model, discretized governing equations and boundary conditions are written in appropriate cells. Calculation is performed automatically to obtain numerical results. In the present study, Excel VBA is introduced and an icon-based visual spreadsheet is developed for heat transfer analysis. It is based on the color-coded cells termed Icon Cell, where a series of discretized equations are embedded in advance. By using macro buttons, the icon cells are arranged on a spreadsheet and they show numerical results immediately. The icon-based Excel simulation does not require any computer program writing, and therefore it is a very handy tool for scientific researches and practical engineering applications.
\end{abstract}

Keywords : Excel simulation, VBA, Macro, Icon cell, Heat transfer

\section{1. 緒 論}

Excel のワークシート上で, 表計算機能を利用して熱 流体のシミュレーションを行う簡易解析手法が提案され ている 1)，21，3). Excel による数值解析では，ワークシー トのセルを格子点とみなし，物理モデルのイメージを描 いた上で，基礎式や境界条件などの離散化方程式を各セ ルに入力して計算結果を得る。本研究では，VBA (Visual Basic for Applications)によるマクロ機能を導 入し, 従来のアイコン化セルによる数值解析手法 ${ }^{3)}$ を発 展させ,ビジュアルな伝熱解析ツールを满築した，二次 元の定常熱伝導問題を対象として具体例を示す.

\section{2. 数値モデル}

\section{1 基碳式と境界条吽}

$x, y$ の二次元直角座標系における定常熱伝導方程式は, 温度 $T$ とすると，次式で与えられる。

$$
\left(\partial^{2} T / \partial x^{2}\right)+\left(\partial^{2} T / \partial y^{2}\right)=0
$$

また境界では，問題に応じて温度 $T_{\mathrm{w}}$ ，熱流束 $q_{\mathrm{w}}$, 対流 による熱伝達等が規定され，それぞれ次式で与えられる。

$$
\begin{gathered}
T_{\mathrm{B}}=T_{\mathrm{w}} \\
-\left.\lambda(\partial T / \partial n)\right|_{\mathrm{B}}= \pm q_{\mathrm{w}} \\
-\left.\lambda(\partial T / \partial n)\right|_{\mathrm{B}}= \pm \alpha\left(T_{\mathrm{s}}-T_{\mathrm{B}}\right)
\end{gathered}
$$

ここで， $\lambda$ は熱伝導率， $n$ は法線方向座標， $\alpha$ は熱伝達 率， $T_{\mathrm{s}}$ は周囲温度であり，下添字 B は境界を表す。

\section{2 離散化}

コントロール・ボリューム法 ${ }^{1)}$ を用いると，Fig. 1(a) により，式(1)は次式のように離散化される。

$$
T_{\mathrm{P}}=\frac{a_{\mathrm{E}} T_{\mathrm{E}}+a_{\mathrm{W}} T_{\mathrm{W}}+a_{\mathrm{N}} T_{\mathrm{N}}+a_{\mathrm{S}} T_{\mathrm{S}}}{a_{\mathrm{E}}+a_{\mathrm{W}}+a_{\mathrm{N}}+a_{\mathrm{S}}}
$$

ここで, $a_{\mathrm{E}}=a_{\mathrm{W}}=\Delta y / \delta x, a_{\mathrm{N}}=a_{\mathrm{S}}=\Delta x / \delta y$ である. また，

Fig. 1(b)により，式(3)，(4)はそれぞれ次式のように雄散 化される.

$$
\begin{gathered}
T_{\mathrm{B}}=\frac{4 T_{\mathrm{I}, 1}-T_{\mathrm{I}, 2} \pm 2 q_{\mathrm{w}} \delta n / \lambda}{3} \\
T_{\mathrm{B}}=\frac{4 T_{\mathrm{I}, 1}-T_{1,2}+2 T_{\mathrm{s}} \alpha \delta n / \lambda}{3+2 \alpha \delta n / \lambda}
\end{gathered}
$$
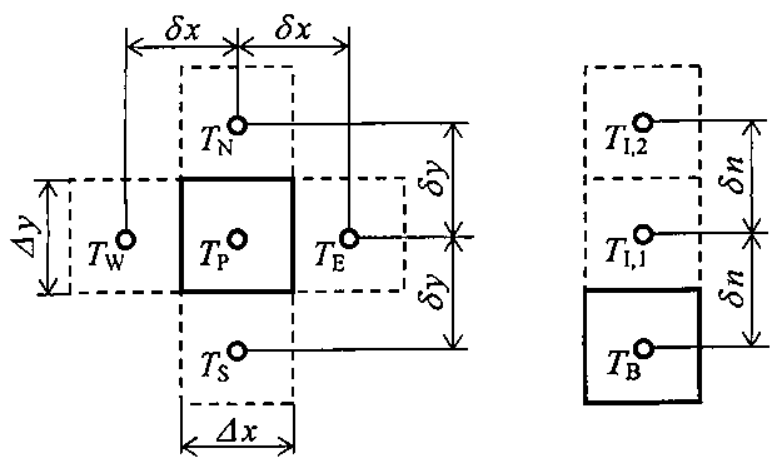
(a) For interior nodes
(b) For boundary nodes

Fig. 1 Control volume. 


\section{Excel 解析}

\section{1 解析ツール}

本研究では，従来のアイコン化セルによる数值解析手

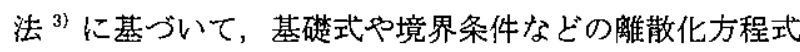
があらかじめ書き込まれ，かつ，その機能がビジュアル に表示されたセルを準備した，Fig. 2 は，そのセルをま とめたワークシートであり，式(6)はセル C4， G4，E2， E6に，式(7)はセル C5， G5，F2，F6にそれぞれ入力さ れている。ささらに，VBAによるマクロ機能を導入し， ボタンを設け，マウスによるドラッグとワンクリックで アイコン化セルを並べ，数値計算を実行できるようにし た。また，式(5)を修正した，

$$
T_{\mathrm{P}}=\frac{\xi_{\mathrm{E}} a_{\mathrm{E}} T_{\mathrm{E}}+\xi_{\mathrm{W}} a_{\mathrm{W}} T_{\mathrm{W}}+\xi_{\mathrm{N}} a_{\mathrm{N}} T_{\mathrm{N}}+\xi_{\mathrm{S}} a_{\mathrm{S}} T_{\mathrm{S}}}{\xi_{\mathrm{E}} a_{\mathrm{E}}+\xi_{\mathrm{W}} a_{\mathrm{W}}+\xi_{\mathrm{N}} a_{\mathrm{N}}+\xi_{\mathrm{S}} a_{\mathrm{S}}}
$$

をセル E4 に埋め込んでおり，内点温度を計算する際に は $\xi_{\mathrm{E}}=\xi_{\mathrm{W}}=\xi_{\mathrm{N}}=\xi_{\mathrm{S}}=1$ とし、コーナ一温度を計算する際 には壁面に沿う隣接点の $\xi$ 1, 他を 0 として, 内点と コーナーの両者の温度計算に対応できるようにした。

\section{2 道用例}

Fig. 3 に，物理モデルの具体例を示した。熱伝導率 $\lambda=$ $20 \mathrm{~W} /(\mathrm{m} \cdot \mathrm{K})$ の縦 $0.15 \mathrm{~m}$, 横 $0.12 \mathrm{~m}$ の矩形領域において, 下壁および左壁は熱流束 $q_{\mathrm{wb}}=q_{\mathrm{wl}}=1.0 \times 10^{4} \mathrm{~W} / \mathrm{m}^{2}$ で一 様加熱され，右壁および上壁は $20^{\circ} \mathrm{C} に$ 保たれている.

Fig. 4 に, この物理モデルに対する Fig. 2 のワーク シートの適用例を示した. ここでは， $\delta x=\Delta x=0.01 \mathrm{~m}$, $\delta y=\Delta y=0.01 \mathrm{~m}$ として計算を実行した，計算に際して は，前報 ${ }^{3)}$ と同じく，まず，ワークシート上に物理モデ ルのイメージを描き，次に，ワークシート上部で，名前 定義による参照機能を利用して各パラメータの值を定め た。なお，右壁および上壁のセルには直接，温度を入力 した. その後, 格子点の種類に応じてマウスで範囲を指 定し、マクロボタンをクリックしてアイコン化セルを並 ベた．計算は直ちに実行され，Fig. 4 はをの結果を示し たものである，図中には，グラフィック機能を利用した 数值結果の可視化例も併示した.

\section{4. 結 論}

Excel VBA によるマクロ機能を導入し，従来のアイ コン化セルを発展させ, ビジュアルな伝熱解析ツールを 構築した.

\section{参考文献}

1) 森下悦生 : Exce で学ぶ流体力学, 丸善 (2000).

2) Holman, J. P.: Heat Transfer (Ninth Edition), McGrawHill, New York (2002) pp.621-655.

3）岩井裕・他 6 名：エクセルそマウスでできる熱流体のシ ミュレーション，丸善 (2005).

4) Patankar, S. V: Numerical Heat Transfer and Fluid Flow, Hemisphere Pub. Co., New York (1980).

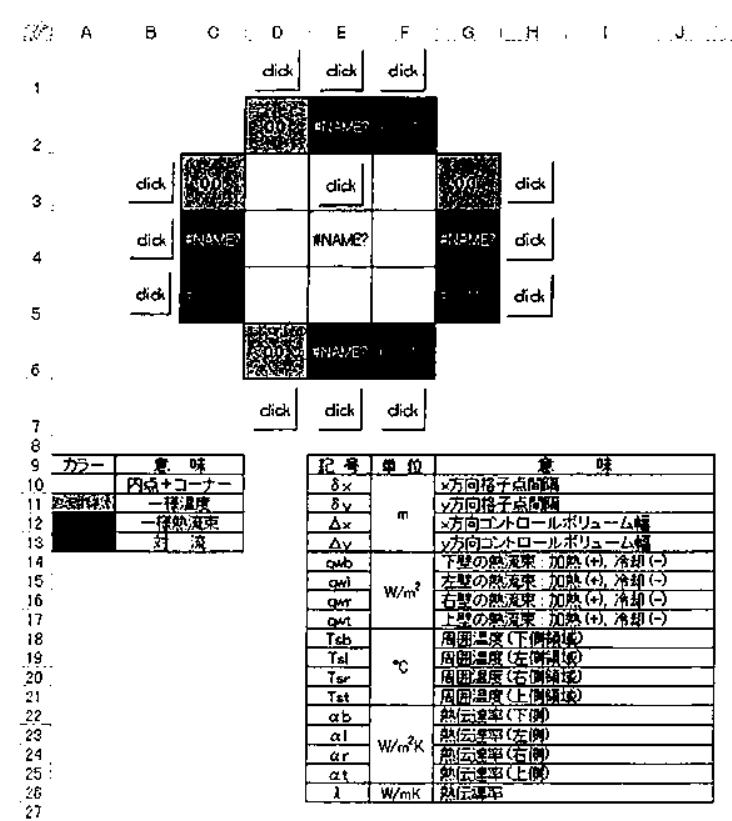

Fig. 2 Icon cell.

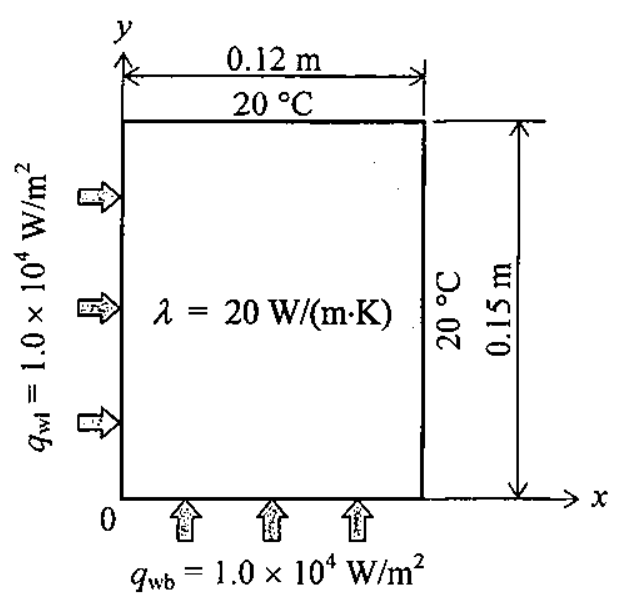

Fig. 3 Physical model.

$\delta_{x} 001$ $\Delta x \quad 0.0$

$8 y \quad 001$

$\Delta y \quad 0.0$

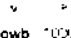
and the

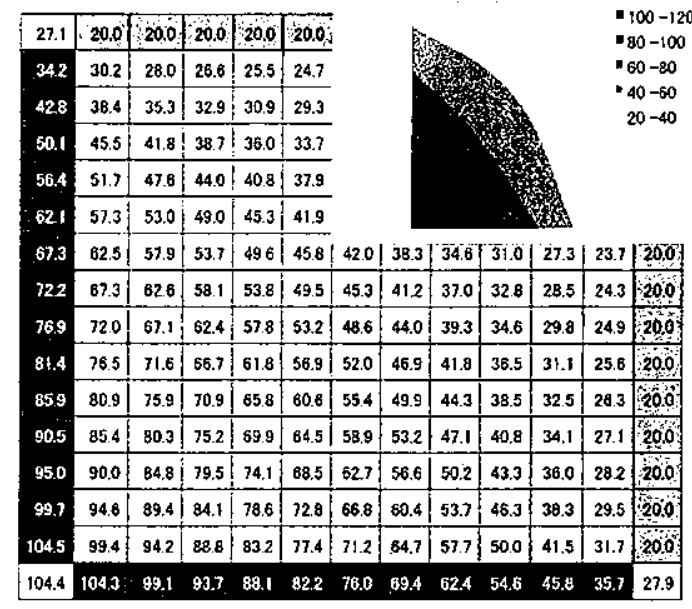

Fig. 4 Numerical results. 